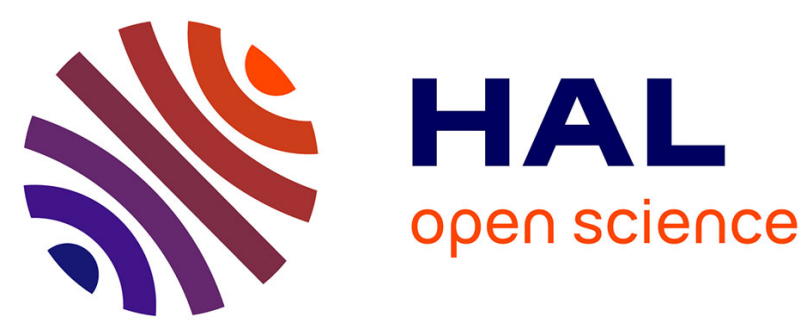

\title{
Assessment of the water stress effects on peach fruit quality and size using a fruit tree model, QualiTree
}

José Manuel Miras Avalos, Rosalía Alcobendas, Juan José Alarcón, Pierre

Valsesia, Michel M. Génard, Emilio Nicolás

\section{- To cite this version:}

José Manuel Miras Avalos, Rosalía Alcobendas, Juan José Alarcón, Pierre Valsesia, Michel M. Génard, et al.. Assessment of the water stress effects on peach fruit quality and size using a fruit tree model, QualiTree. Agricultural Water Management, 2013, 128, pp.1-12. 10.1016/agwat.2013.06.008 . hal02643177

\section{HAL Id: hal-02643177 \\ https://hal.inrae.fr/hal-02643177}

Submitted on 28 May 2020

HAL is a multi-disciplinary open access archive for the deposit and dissemination of scientific research documents, whether they are published or not. The documents may come from teaching and research institutions in France or abroad, or from public or private research centers.
L'archive ouverte pluridisciplinaire HAL, est destinée au dépôt et à la diffusion de documents scientifiques de niveau recherche, publiés ou non, émanant des établissements d'enseignement et de recherche français ou étrangers, des laboratoires publics ou privés. 
Version définitive du manuscrit publiée dans / Final version of the manuscript published in :

Agricultural Water Management (2013), Vol. 128, p. 1-12, DOI: 10.1016/agwat.2013.06.008,

Journal homepage: http://www.elsevier.com/locate/agwat

\section{AGRICULTURAL WATER MANAGEMENT}

Type of paper: Original paper (Regular paper)

Title: Assessment of the water stress effects on peach fruit quality and size using a fruit tree model, QualiTree

\section{Authors names and addresses:}

José M. Mirás-Avalos ${ }^{1,2}$, Rosalía Alcobendas ${ }^{3,4}$, Juan José Alarcón ${ }^{3,4}$, Pierre Valsesia ${ }^{5}$, Michel Génard $^{5}$, Emilio Nicolás ${ }^{3,4}$

\footnotetext{
${ }^{1}$ Facultad de Ciencias. Universidade da Coruña. Campus de A Zapateira s/n. A Coruña, Spain.
}

${ }^{2}$ Present address: Estación de Viticultura y Enología de Galicia (EVEGA). Ponte San Clodio s/n 32427, Leiro (Ourense), Spain

${ }^{3}$ Departamento de Riego, Centro de Edafología y Biología Aplicada del Segura, CSIC, P.O. Box 164, 30100, Espinardo (Murcia), Spain

${ }^{4}$ Unidad Asociada al CSIC de Horticultura Sostenible en Zonas Áridas (UPCT-CEBAS), Paseo Alfonso XIII, s/n. 30203, Cartagena (Murcia), Spain

${ }^{5}$ UR1115 Plantes et Systèmes de Culture Horticoles (PSH), INRA, Domaine Saint-Paul, Site Agroparc, 84914 Avignon Cedex 9, France

\section{Corresponding author: José Manuel Mirás-Avalos} Estación de Viticultura y Enología de Galicia (EVEGA). Ponte San Clodio s/n 32427, Leiro (Ourense), Spain Phone: +34 988488033

Fax: +34988488191

E-mail: jmirasa@udc.es

Number of tables: 5

Number of figures: 6

Page count: 37 (including this one)

\section{Research highlights:}

- A middle-late maturing peach cultivar was successfully implemented into QualiTree.

- QualiTree was able to adequately simulate the effects of water stress on fruit growth.

- Fructose, glucose and sorbitol contents in the fruit flesh were well simulated.

- Water stress increased sugar contents in the fruit flesh. 
Version définitive du manuscrit publiée dans / Final version of the manuscript published in :

Agricultural Water Management (2013), Vol. 128, p. 1-12, DOI: 10.1016/agwat.2013.06.008,

Journal homepage: http://www.elsevier.com/locate/agwat

37 Abstract

Low water availability has increased the use of regulated deficit irrigation strategies in

fruit orchards. However, these water restrictions may have implications on fruit growth and quality. The current paper assesses the suitability of an existing fruit tree model (QualiTree) for describing the effects of water stress on peach fruit growth and quality. The model was parameterised and calibrated for a mid-late maturing peach cultivar ('Catherine'). Mean and variability over time of fruit and vegetative growth were consistent with observed data on trees submitted to full irrigation or to regulated deficit irrigation. The relative root mean square errors of the model for growth ranged between 0.09 and 0.31 .

Sugar contents in fruit flesh were fairly well simulated, except for sucrose, which was overestimated. The relative root mean square errors of the model ranged from 0.01 to 0.40 for fructose; from 0.04 to 0.05 for glucose; from 0.21 to 0.41 for sucrose and from 0.09 to 0.28 for sorbitol. Water stress reduced leafy shoot growth up to $23 \%$ and fruit final size up to $49 \%$ when compared to the well-watered control. However, sugar contents in the flesh increased with water stress, up to $70 \%$ in the case of glucose. Simulations showed that a severe water stress during stage III of fruit development decreased fruit sizes by $22 \%$, when compared to the control, whereas it enhanced sugar accumulation in the fruit flesh, up to $70 \%$ in the case of glucose and fructose. Therefore, these simulations showed that QualiTree might be useful in the design of innovative horticultural practices.

Keywords: Prunus persica L. Batsch, fruit quality, reducing sugars, modelling, regulated deficit irrigation, crop production

\section{Introduction}

Regulated deficit irrigation (RDI) practices are common for peach-tree cultivation in order to save water. This may impose serious water restrictions to the trees. For instance, in Spain, where peach (Prunus persica L. Batsch) culture is highly important, restrictions in 
Version définitive du manuscrit publiée dans / Final version of the manuscript published in :

Agricultural Water Management (2013), Vol. 128, p. 1-12, DOI: 10.1016/agwat.2013.06.008,

Journal homepage: http://www.elsevier.com/locate/agwat

65

66

67

68

69

70

71

maturing cultivars (Lopez et al., 2010); this coincides with the final stage of fruit development (stage III), which is characterized by a high accumulation of fresh and dry weight by the fruit.

Those water restrictions not only may have an effect on fruit size, but also on fruit quality, which is an important issue for fruit production and retailing (Codron et al., 2005). For instance, Berman and DeJong (1996) reported that water stress at stage III limits fruit growth. Hence, marketable fruit size may not be attained. However, other fruit quality criteria could be positively affected, such as soluble solid content in fruit flesh (Crisosto et al., 1994). In this sense, Lopez et al. (2010), studying deficit-irrigated mid-late maturing 'O'Henry' peach, found that RDI significantly increased soluble solid contents. On other species from the Prunus genre, such as plum, deficit irrigation has also been reported to increase total soluble solids content in fruits (Intrigliolo and Castel, 2010).

Fruit quality involves a set of traits such as fruit size, overall composition and taste, and proportion of edible tissue (Génard et al., 2009). These traits result from many processes at both the plant and organ levels that show large genotype $\mathrm{x}$ environment (management) interactions (Aguirrezábal et al., 2009). Understanding all the interactions between factors affecting fruit quality and the inherent complexity of its build-up is a challenging subject. In this sense, process-based simulation models may be useful tools to discern the complex linked processes controlling fruit size and composition at different levels of organization (Martre et al., 2011). Although several models for simulating fruit-tree functioning have been developed for apple (Costes et al., 2008) and peach (L-PEACH: Allen et al., 2005), accounting for the effect of water stress on carbon partitioning in the latter case (Da Silva et al., 2011), they are not focused on fruit quality. Recently, Lescourret et al. (2011) presented QualiTree, a model that combines physiological and agronomic viewpoints for describing carbon allocation within the tree, vegetative and fruit growth distribution and the development of fruit quality. Because of its parsimony, QualiTree is more convenient than the previous models for quantitative comparison of data for parameterization and evaluation.

In its present state, QualiTree has not been validated with experimental data on sugar concentrations in fruit flesh. Furthermore, the results reported by Mirás-Avalos et al. (2011) 
Version définitive du manuscrit publiée dans / Final version of the manuscript published in :

Agricultural Water Management (2013), Vol. 128, p. 1-12, DOI: 10.1016/agwat.2013.06.008,

Journal homepage: http://www.elsevier.com/locate/agwat

93 suggest that some parameters within QualiTree are cultivar-dependent. Therefore, the aim of

94 the present work was to validate QualiTree sugar sub-model for a mid-maturing peach tree

95 cultivar (the previous studies were done on early and late maturing cultivars, Mirás-Avalos et

96 al., 2011, 2012) and to use the predictive capabilities of the model for evaluating the effects of water restrictions on fruit and vegetative growth, and also on sugar concentrations in the fruit flesh.

First, QualiTree was parameterised for a mid-maturing peach cultivar (cv. 'Catherine')

100 and validated with observed data from different situations concerning irrigation conditions. The

101 variables considered were the fruit and the leafy shoot dry masses, and the concentrations of 102 four sugars (sucrose, glucose, fructose, and sorbitol) in the fruit. Then, we designed several 103 simulation scenarios to observe the response of the model. Some of these scenarios were 104 theoretical for testing the behaviour of the model and some others were constructed using field 105 observations involving deficit irrigation practices as a basis.

\section{2. Materials and methods}

108 2.1. QualiTree, model overview

109 QualiTree (Lescourret et al., 2011) is a generic fruit tree model that describes the tree as 110 a set of objects: fruiting units (FU) composed of fruits, leafy shoots and stem wood in a tree 111 architecture, and other compartments viewed globally: old wood (trunk and branches), coarse 112 roots, and fine roots. QualiTree runs, on a daily timestep, from bloom or after bloom until the 113 end of the fruit growing season, starting from an initial state of the tree.

114 In order to represent the growth in dry mass of all the tree objects, QualiTree uses a 115 carbon-supply approach, allocation rules (priority sequence between processes - e.g., 116 maintenance, then growth - or organs -e.g., leafy shoot growth, then fruit growth; use of 117 reserve as buffers; passive carbon storage), and equations of carbon assimilation (based on leaf 118 area for photosynthesis) and growth requirements (demands). These equations are taken mainly 119 from the FU carbon model of Lescourret et al. (1998). 
Version définitive du manuscrit publiée dans / Final version of the manuscript published in :

Agricultural Water Management (2013), Vol. 128, p. 1-12, DOI: 10.1016/agwat.2013.06.008,

Journal homepage: http://www.elsevier.com/locate/agwat

Briefly, to restore carbon balance within the tree, two main principles are applied. First,

121 the coordination theory (Reynolds and Chen, 1996; Chen and Reynolds, 1997) is used to

122 propose that the imbalance $(\mathrm{Im})$ between leafy shoots and fine roots defined as the ratio of dry

123 structural masses of young shoots and fine roots to the shoot:root ratio at equilibrium (model

124 parameter, SReq) changes the demands of leafy shoots and fine roots. Second, carbon

125 exchanges occur between the tree objects, with proportionality to the supply of the donor, the

126 demands of the recipient and a decreasing effect of geometric distance between donor and

127 recipient objects according to a negative power law. The core of these carbon balance principles

128 lies on three main equations. First, the demands of the stem wood, old wood and coarse root

129 compartments are based on the following equation of potential growth in dry mass (DM, g)

130 according to degree-days (dd):

131

$$
\frac{\Delta D M_{x}}{\Delta d d}=R G R_{x}^{i n i} D M_{x} e^{-\theta_{\lambda} d d}
$$

133 where subscript $x$ is $s w$ for stem wood, ow for old wood and $c r$ for coarse roots, $R G R_{x}^{i n i}$, the initial relative growth rate, and $\theta_{\lambda}$ are parameters $\left(\mathrm{dd}^{-1}\right)$.

Second, the demands of fruit or leafy shoots of the FU and of fine roots are based on the

136 following equation of potential growth:

$$
\frac{\Delta D M_{x}}{\Delta d d}=R G R_{x}^{i n i} \operatorname{Im}^{a} g(d d) D M_{x}\left(1-\frac{D M_{x}}{\operatorname{Im}^{a} D M_{x}^{\max }}\right)
$$

139 where subscript $x$ is $f$ for fruit, $l s$ for leafy shoots and $f r$ for fine roots, $R G R_{x}^{i n i}\left(\mathrm{dd}^{-1}\right)$ is the initial

140 relative growth rate (model parameter), Im (dimensionless) is the imbalance between leafy

141 shoots and fine root masses defined previously, exponent $a$ is 0 for fruit, -1 for leafy shoots and

1421 for roots, and $g(d d)$ is defined as:

$143 \quad g(d d)=1$ if $d d<d d_{\min }$

$144 \quad g(d d)=\frac{d d_{\text {max }}-d d}{d d_{\text {min }}-d d}$ if $d d$ is between $d d_{\text {min }}$ and $d d_{\text {max }}$ 
Version définitive du manuscrit publiée dans / Final version of the manuscript published in :

Agricultural Water Management (2013), Vol. 128, p. 1-12, DOI: 10.1016/agwat.2013.06.008,

Journal homepage: http://www.elsevier.com/locate/agwat

$145 \quad g(d d)=0$ if $d d>d d \max$

146 with $d d_{\min }$ and $d d_{\max }$ as organ-specific parameters (dd).

$D M_{f}^{\max }(\mathrm{g})$ is the maximum dry mass of a fruit. $D M_{l s}{ }^{\max }$ is the product of the leafy shoot

148 number of the FU and the maximum mass of an average individual leafy shoot $D M_{i l s}{ }^{m a x}$. Respect

149 to the set of fine roots, $\mathrm{DM}_{\mathrm{fr}}^{\max }$ is calculated assuming that its ratio to the maximum mass of

150 leafy shoots on the tree is equal to the shoot:root ratio at equilibrium, SReq:

$151 \quad D M_{f r}^{\max }=\frac{N_{l s} D M_{i l s}^{\max }}{S \operatorname{Re} q}$

152 where $N_{l s}$ is the number of leafy shoots on the tree.

153 Third, the equation depicting the carbon flow $F_{i j}$ between two object $i$ and $j$ of the tree

154 is:

$F_{i j}=\frac{A C P_{i} \text { Demand }_{j}}{\sum_{j=1}^{n} \text { Demand }_{j}}$ dist $_{i j}^{-k}$

156 where $A C P_{i}$ is the available carbon pool of $i(\mathrm{gC})$, i.e., the carbon pool remaining after satisfaction of maintenance respiration (and of leaf growth if $i$ is an FU) from an initial pool made of photosynthates (if $i$ is an $\mathrm{FU}$ ) and of mobilised reserves, Demand $_{j}(\mathrm{gC})$ is the carbon

159 demand of $j$, dist $t_{i j}(\mathrm{~mm})$ the geometric distance between $i$ and $j, n$ is the total number of objects

160 exchanging carbon and $k$ is a positive parameter (dimensionless). Parameter $k$ expresses the

161 effect of distance on carbon exchange: when $k$ is close to zero, the distance has no effect and

162 carbon is distributed proportionally to carbon demands, whereas high values for $k$ lead to severe effects of distance.

Several fruit quality traits (fruit size, the proportion of the total mass consisting of fruit

165 flesh, dry matter content of the flesh, concentrations of various sugars, and a sweetness index)

166 are also represented by QualiTree.

167 Fruit sugar content seasonal variation is described as a set of differential equations 168 proposed by Génard et al. (2003):

$$
\frac{d M_{s u}}{d t}=\lambda_{p h} \frac{d M_{p h}}{d t}-k_{1}(t) M_{s u}
$$


177 sorbitol, glucose and fructose, respectively; $\frac{d M_{p h}}{d t}$ is the phloem flux of carbon into the fruit;

$\frac{d M_{r e}}{d t}$ is the amount of carbon used for respiration; $D M$ is the dry mass of fruit flesh; $\lambda_{p h}$ is the

179 proportion of sucrose in the phloem-sourced sugar pool resulting from plant metabolism; and $k_{1}(t), k_{2}, k_{3}$ and $k_{4}(t)\left(\right.$ day $\left.^{-1}\right)$ are, respectively, the relative rates of sucrose transformation to glucose and fructose, net sorbitol transformation to glucose, net sorbitol transformation to fructose, and the synthesis of compounds other than sugars from glucose and fructose. $k_{l}(t)$ decreases over time, and depends on two parameters : $k_{1.1}\left(\right.$ day $\left.^{-1}\right)$ which is the relative rate of decrease of $k_{l}(t)$ and $k_{1.2}$ (day) which is the time at which $k_{l}(t)$ equals 1 day $^{-1} . k 4(t)$ varies during the season like the relative growth rate, with a proportionality factor $k_{4}$.

187 (Mirás-Avalos et al., 2011). Combining QualiTree with a simple light interception model allows

188 one to account for light interception, its alteration during the season through variations of the leaf area density, and the consequences on photosynthesis of each FU (Mirás-Avalos et al., 2011). Briefly, this light interception model predicts radiation interception by a tree, based on 
Version définitive du manuscrit publiée dans / Final version of the manuscript published in :

Agricultural Water Management (2013), Vol. 128, p. 1-12, DOI: 10.1016/agwat.2013.06.008,

Journal homepage: http://www.elsevier.com/locate/agwat

191 the works by Charles-Edwards and Thornley (1973) and de Pury and Farquhar (1997). The tree

192 is within an orchard and its canopy is represented by simple geometric shapes (ellipses).

193 QualiTree modelises the effect of water stress on the plant development by correcting

194 the rate of light-saturated leaf photosynthesis (Ben Mimoun et al., 1999); this deals directly with

195 source limitation and is accounted for, in the model, through an equation (Harrison et al., 1989)

196 relying the light-saturated leaf photosynthesis to the leaf water potential:

197

$$
P_{\max }=P_{\max 0} \cdot\left(1-\exp ^{\left(B_{h}\left(A_{h}+W P^{-1}\right)\right)}\right)
$$

198 where $P_{\max }$ is the potential photosynthesis rate $\left(\mathrm{mmol} \mathrm{CO}_{2} \mathrm{~m}^{-2} \mathrm{~s}^{-1}\right), P_{\max 0}$ is the maximal

199 photosynthesis rate $\left(\mathrm{mmol} \mathrm{CO} \mathrm{CO}^{-2} \mathrm{~s}^{-1}\right)$ without water stress which depends on the level of

200 reserves in the leaf, $A_{h}$ and $B_{h}$ are specific parameters $\left(0.22 \mathrm{MPa}^{-1}\right.$ and $4.43 \mathrm{MPa}$, respectively),

201 and $W P$ is the leaf water potential.

202 Furthermore, water management in the fruit obeys a series of equations adapted from

203 Fishman and Génard (1998) in Lescourret and Génard (2005). The effect of irrigation is considered through plant water potential, which plays a major role in these equations.

205

For a complete list of Qualitree inputs and outputs, see the Electronic Supplementary

Material, Tables S1 and S2).

207

208

\subsection{Experimental data}

209

The experiment concerned a middle-late-maturing cultivar of Prunus persica (cv.

210 Catherine). Catherine data were collected in 2008 on a 0.5 ha orchard planted in 1999 at the

211 CEBAS-CSIC experimental station in Fuente Librilla, Murcia, Spain $\left(37^{\circ} 55^{\prime} \mathrm{N}, 1^{\circ} 25^{\prime} \mathrm{W}, 360\right.$

$212 \mathrm{~m}$ altitude). Trees were grafted on GF677 rootstock and planted at $4 \mathrm{~m} \times 6 \mathrm{~m}$ spacings on a

213 clay-loam soil. Pest control and fertilization practices were those commonly used by the

214 growers. Trees were hand-thinned 30 days after full-bloom (DAFB), which occurred on March

215 18. Harvest date was July 1.

216 Two different irrigation treatments were considered in this study. A full irrigation

217 treatment (FI) where trees were irrigated with enough water to replace $100 \%$ of crop 
Version définitive du manuscrit publiée dans / Final version of the manuscript published in :

Agricultural Water Management (2013), Vol. 128, p. 1-12, DOI: 10.1016/agwat.2013.06.008,

Journal homepage: http://www.elsevier.com/locate/agwat

218 evapotranspiration $\left(\mathrm{ET}_{\mathrm{c}}\right)$ requirements and a regulated deficit irrigation treatment (RDI)

219 established to adjust a pre-defined threshold of stem water potential $\left(\psi_{\mathrm{s}}\right)$ of $-1.5 \mathrm{MPa}$, where a

220 moderate water deficit is applied in a closely controlled way in low stress sensitivity periods

221 (stage II of fruit development defined by a slowing of the diametral growth and stone hardening;

222 Girona et al., 2005). Crop irrigation requirements in FI were determined according to daily crop

223 reference evapotranspiration $\left(\mathrm{ET}_{0}\right)$, calculated with the Penman-Monteith equation, a crop factor

224 that varied during the year (Allen et al., 1998) and the percentage of ground area shaded by the

225 tree canopy (Fereres and Goldhamer, 1990). In RDI, applied irrigation doses and frequency

226 were continuously adjusted to match the average pre-defined $\psi_{\mathrm{s}}$ value. The cumulative annual

227 amount of irrigation water for FI and RDI was 750.1 and $460.2 \mathrm{~mm}$, respectively. An experimental design layout is shown in Fig. 1.

Tree water status was assessed through regular measurements (3 days) of leaf $\left(\psi_{1}\right)$ and stem $\left(\psi_{\mathrm{s}}\right)$ water potentials. Measurements were performed in two leaves from two trees per replication (i.e. 8 trees per treatment, thus 16 leaves per treatment and measurement date) using

232 a pressure chamber (Soil Moisture Equipment Corp. Model 3000, Santa Barbara, CA, USA).

233 The leaves used for these determinations were mature, healthy and from the north face of the

234 tree near the trunk. For $\psi_{\mathrm{s}}$ measurements, each leaf was individually enclosed in a plastic bag 235 and wrapped in aluminium foil for at least $2 \mathrm{~h}$ prior to the measurements. This inhibits leaf transpiration and makes it possible for the water potential in the leaf xylem to be in equilibrium with that of stem xylem at the point of attachment of the petiole.

238 In FI trees, $\psi_{\mathrm{s}}$ decreased from $-0.4 \mathrm{MPa}$ at the beginning of the stage II of fruit growth to -0.7

$239 \mathrm{MPa}$ in stage III, whereas in RDI trees $\psi_{\mathrm{s}}$ ranged between -0.55 and $-0.85 \mathrm{MPa}$ during fruit 240 development. In the case of $\psi_{1}$, average values for stage II and stage III ranged, respectively 241 from -1.05 to $-1.65 \mathrm{MPa}$ for FI trees and from -1.45 to $-1.85 \mathrm{MPa}$ for RDI trees. These values were considered in the design of simulation scenarios. Both FI and RDI trees presented the stages of fruit development on the same dates. Stage III of peach fruit development begins when

244 the stone is formed and the fruit starts to grow rapidly again. 
Version définitive du manuscrit publiée dans / Final version of the manuscript published in :

Agricultural Water Management (2013), Vol. 128, p. 1-12, DOI: 10.1016/agwat.2013.06.008,

Journal homepage: http://www.elsevier.com/locate/agwat

Three trees within the orchard were chosen as being representative of these treatments.

246 They are referred to hereinafter as FI Tree 1, FI Tree 2, and RDI. Diameters, lengths of the tree

247 axes, insertion and phyllotaxic angles were measured in order to obtain a description of the tree

248 architecture. FI Tree 1 was used for parameterization purposes and the remaining two trees,

249 namely FI Tree 2 and RDI, were used to test the model.

250 For these three trees, the diameters (FD, in $\mathrm{mm}$ ) of all fruits were measured

251 perpendicularly to the fruit suture on each FU using digital callipers. Data were collected every

252 5-7 days from 57 DAFB until 105 DAFB, when the fruit growth curves displayed a saturation

253 pattern. FD was converted to dry mass (DM, in g) using an allometric relationship derived from experimental data $\left(\mathrm{DM}=1.7429 \times 10^{-5} \times \mathrm{FD}^{3.2654}, \mathrm{n}=143, \mathrm{r}^{2}=0.96\right)$. Leafy shoot length $(\mathrm{m})$ was also measured for each FU four times during fruit growth. Lengths were converted to dry mass (g) using an allometric relationship derived from experimental data $(D M=16.1 \times$ length; $n=61)$.

Randomly, twenty fruits from each treatment were collected on two different dates (66 and 94 DAFB) prior to harvest for sugar analysis. At harvest (105 DAFB), all fruits from each tree were used for sugar analysis. Samples were frozen in liquid nitrogen for preservation before analysis. Soluble sugar (sucrose, glucose, fructose and sorbitol) contents in fruits were determined by high performance liquid chromatography (HPLC) as described by Gomez et al. (2002).

\subsection{Input data}

Climate data (including global solar radiation and temperature), collected at a weather station located into the experimental field, was used as a model input. Leaf and stem water potential values, for simulating plant water status, were also provided.

Data on diameter and length of the different tree parts at full bloom (i.e., trunk, scaffolds, branches and FU) were used to calculate distances between the virtual tree objects and their initial dry masses as described in Mirás-Avalos et al. (2011). Distances between FUs 
Version définitive du manuscrit publiée dans / Final version of the manuscript published in :

Agricultural Water Management (2013), Vol. 128, p. 1-12, DOI: 10.1016/agwat.2013.06.008,

Journal homepage: http://www.elsevier.com/locate/agwat

272 et al., 2011). For instance, the whole set of distances ranged from 1 to $455 \mathrm{~cm}$ in FI Tree 1

$273 \quad$ (average $=263.3 \mathrm{~cm}$ )

274 The initial dry mass of fine roots was assumed to be proportional to the current-year 275 aboveground parts of the tree (Kozlowski et al., 1991).

Maximum carbon reserve accumulation was defined for each tree compartment as a percentage of its dry mass. Old wood $(8 \%)$ and coarse roots $(8 \%)$ carbon reserve values were

278 taken from the works of Jordan and Habib (1996) and Mediene et al. (2002). Reserve values for 279 stems (5.5\%) and leafy shoots $(16 \%)$ at the initial stage of fruit development were obtained 280 from Lescourret and Génard (2005). The list of QualiTree inputs is presented in Table S1 of the 281 Electronic Supplementary Material.

282

\subsection{Estimation of parameters}

Some parameters concerning the carbon economy in QualiTree depended on the cultivar

285 (Mirás-Avalos et al., 2011). Table 1 presents the parameters which were estimated in this work.

286 All other parameters were taken from Génard et al. (1998), Lescourret et al. (1998), Lescourret 287 and Génard (2005) and Mirás-Avalos et al. (2011). In the Electronic Supplementary Material, 288 Table S3 presents the complete list of parameters.

Potential fruit and leafy shoot growth parameters, namely the initial relative growth rate $290\left(R G R^{n i}\right)$, maximal dry mass $\left(D M^{\max }\right)$, and minimum and maximum degree-days $\left(d d_{\min }, d d_{\max }\right)$ 291 were estimated using non-linear least squares regressions. Data used for this parameterisation 292 consisted of 24 masses for 8 dates corresponding to the higher values in the data set (90\% 293 quantile at each date).

294 The parameters for the sugar submodel were estimated by maximizing likelihood by the 295 Generalized Reduced Gradient method as reported by Génard et al. (2003).

Three parameters were estimated globally by running QualiTree for Catherine: the

297 parameter expressing the effect of distance between tree objects on carbon exchange within the 298 tree $(k)$; the initial relative growth rate of fine roots $\left(R G R_{f r}{ }^{i n i}\right)$ and that of old wood $\left(R G R_{o w}{ }^{i n i}\right)$. 
Version définitive du manuscrit publiée dans / Final version of the manuscript published in :

Agricultural Water Management (2013), Vol. 128, p. 1-12, DOI: 10.1016/agwat.2013.06.008,

Journal homepage: http://www.elsevier.com/locate/agwat

299 The value of the initial relative growth rate of coarse roots $\left(R G R_{c r}{ }^{i n i}\right)$ was considered to be equal

300 to that of the old wood.

301 The criterion $(A)$ to be minimised for this estimation was a weighted sum of differences

302 averaged over the FU, for the leafy shoot and fruit dry masses:

303

$A=\frac{1}{\sigma_{y}^{2}} \frac{1}{n} \sum_{i}\left[\frac{1}{n_{i}} \sum_{j=1}^{n_{i}}\left(y_{i j}-y_{i j}^{s}\right)^{2}\right]+\frac{1}{\sigma_{z}^{2}} \frac{1}{n} \sum_{i}\left[\frac{1}{n_{i}} \sum_{j=1}^{n_{i}}\left(z_{i j}-z_{i j}^{s}\right)^{2}\right]$

304

where $y_{i j}$ and $z_{i j}$ are the observed average for leafy shoot and fruit dry mass per FU $(i)$ and per

305

date $(j)$, respectively; $y_{i j}^{s}$ and $z_{i j}^{s}$ the corresponding simulated average values of leafy shoot and

fruit dry mass per FU $(i)$ and per date $(j)$, respectively; $n_{i}$, the number of dates for FU $(i) ; n$, the total number of FU; $\sigma_{y}^{2}$, the variance of $y_{i j}$; and $\sigma_{z}^{2}$, the variance of $z_{i j}$.

308

309

\subsection{Comparison of observed and simulated values}

310 The observed and simulated values of fruit or leafy shoot dry masses per FU at the same

311 dates were compared using the Relative Root Mean Square Error (RRMSE), a common

312 criterion for evaluating non-linear models (Kobayashi and Salam 2000), here defined as:

$$
R R M S E=\frac{1}{\bar{y}} \sqrt{\frac{1}{N} \sum_{i=1}^{N}\left(y_{i}-y_{i}^{s}\right)^{2}}
$$

314 where $y_{i}$ is the observed value, $y_{i}^{s}$ the corresponding simulated value, $N$ the number of

315 observed data, and $\bar{y}$ the mean of observed values. This index represents the mean distance

316 between simulation and measurement. The smaller the RRMSE, the more accurate the

317 simulation.

\subsection{Simulation scenarios}

To test the effects of deficit irrigation and water stress on vegetative and fruit growth, and on fruit sugar development, several simulation scenarios were designed. Water stress scenarios were described through the definition of $\psi_{1}$ and $\psi_{\mathrm{s}}$, known to give the plant water status (Choné et al. 2001). 
Version définitive du manuscrit publiée dans / Final version of the manuscript published in :

Agricultural Water Management (2013), Vol. 128, p. 1-12, DOI: 10.1016/agwat.2013.06.008,

Journal homepage: http://www.elsevier.com/locate/agwat

A first series of five scenarios aimed at testing the behaviour of the model regarding

325 fruit and leafy shoot growth and sugar concentrations for a range of constant leaf and stem water

326 potential values. Respectively, $\psi_{1}$ and $\psi_{\mathrm{s}}$ ranged from -0.8 and $-0.6 \mathrm{MPa}$ (control) to -3 and -1.3

327 MPa (very severe stress; Table 2). In these scenarios, water stress began when simulation

328 started. Moreover, four additional scenarios were simulated (Table 2) with a water stress

329 produced either in stage II or in stage III of fruit development, in order to observe the model's

330 response. Those scenarios reproducing a water stress occurring on stage II were divided in three

331 periods of, approximately, two weeks each: from 57 to $75 \mathrm{DAFB}, \psi_{1}$ and $\psi_{\mathrm{s}}$ were those of non-

332 stress conditions i.e. -0.8 and $-0.6 \mathrm{MPa}$, respectively; from 76 to $89 \mathrm{DAFB}, \psi_{1}$ and $\psi_{\mathrm{s}}$ were -1.5

333 and $-0.9 \mathrm{MPa}$ (in the case of moderate water stress) and -3.0 and $-1.6 \mathrm{MPa}$ (in the case of severe water stress), respectively; from 90 to 105 DAFB (harvest), leaf and stem water potentials were those of non-stress conditions.

Scenarios reproducing water stress during stage III were also built. We maintained $\psi_{1}$ and $\psi_{\mathrm{s}}$ at -0.8 and $-0.6 \mathrm{MPa}$, respectively, from 57 to $89 \mathrm{DAFB}$, and then, we decreased $\psi_{1}$ and $\psi_{\mathrm{s}}$ until harvest to -1.5 and $-0.9 \mathrm{MPa}$ for a moderate water stress and to -3.0 and $-1.6 \mathrm{MPa}$ for a severe water stress.

These values were chosen from an equation relating three-year data of leaf and stem water potentials for this peach cultivar under the climatic conditions of the studied region (unpublished data).

Other three water stress scenarios were defined considering leaf and stem water

344 potentials reported for peach trees in experimental orchards under different irrigation conditions

345 (e.g., Berman and DeJong, 1996; Besset et al., 2001; Solari et al., 2006; Conejero et al., 2007;

346 López et al., 2008; Mercier et al., 2009; Abrisqueta et al., 2010; Bussi et al., 2010; López et al.,

347 2010). These agronomic scenarios describe three different situations: (i) a control with no water 348 restrictions although the values of water potential fluctuate over the growing period; (ii) a

349 situation of moderate stress, which can be regarded as a scenario of RDI; and (iii) a situation of 350 a severe water stress, which may be due to high water requirements and low water availability. 
Version définitive du manuscrit publiée dans / Final version of the manuscript published in :

Agricultural Water Management (2013), Vol. 128, p. 1-12, DOI: 10.1016/agwat.2013.06.008,

Journal homepage: http://www.elsevier.com/locate/agwat

The scenarios were analysed by means of analyses of variance using water stress as

352 explaining factor. The output variables were fruit yield in dry mass, fruit average dry mass, total

353 dry mass of leafy shoots, average dry mass of leafy shoots and the concentrations in the fruit

354 flesh of sucrose, glucose, fructose and sorbitol. Tukey's test at 5\% level was used for mean separation.

Data analyses were carried out using R software version 2.12.1 (R Development Core

357 Team, 2010).

358

359 3. Results

360

\subsection{Parameterisation and test of the model}

361

Parameter values are indicated in table 1. Interestingly, a very low value of the

parameter expressing the effect of distance between tree objects on carbon exchange within the

tree $(k)$ was observed (Table 1). This indicates within-tree distances are not a limitation. It is

364

also worth noting that the rate of sorbitol transformation to fructose $\left(k_{3}\right)$ was greater than that

to glucose $\left(k_{2}\right)$ (Table 1).

Simulated leafy shoot dry masses fitted correctly those observed. The variability of the simulated values was similar to that measured in the field (Fig. 2). RRMSE values were 0.09, 0.28 , and 0.15 for FI Tree 1, FI Tree 2 and RDI, respectively. These values correspond to the calibration of the model in the case of FI Tree 1 and to the validation of the model in the case of the FI Tree 2 and RDI Tree.

In the case of fruit growth, the simulated patterns of fruit dry masses correctly fitted for FI Tree 1, when predictions were lower than observations on the three last dates for FI Tree 2

373 (Fig. 2). In RDI tree, there was a good agreement between simulations and observations, except

374 at harvest were the model slightly underestimated the fruit mass. The variability of the observed 375 and simulated values was very similar. The RRMSE values were $0.21,0.30$, and 0.31 for FI

376 Tree 1, FI Tree 2 and RDI, respectively. 
Version définitive du manuscrit publiée dans / Final version of the manuscript published in :

Agricultural Water Management (2013), Vol. 128, p. 1-12, DOI: 10.1016/agwat.2013.06.008,

Journal homepage: http://www.elsevier.com/locate/agwat

378 similar to those measured except for sucrose, which was clearly overestimated (Fig. 3). The

379 dynamics of sugars in the fruit over the growing season were similar for the three trees

380 considered. In all cases, the variability of simulated values was lower than that of the measurements (Fig. 3). The RRMSE values for glucose, fructose, sucrose and sorbitol were, respectively, 0.04, 0.01, 0.32, 0.09 for FI Tree 1; 0.05, 0.08, 0.21, 0.28 for FI Tree 2; and 0.04, $0.40,0.41$ and 0.13 for RDI Tree.

\subsection{Simulation scenarios}

Water stress applied during all the season negatively affected both leafy shoot, fruit growth and yield (Fig. 4). In the case of leafy shoots, the decrease in dry mass at harvest between the control scenario and the most stressful conditions (-3 MPa and $-1.3 \mathrm{MPa}$ for $\psi_{1}$ and $\psi_{\mathrm{s}}$, respectively) was $23 \%$. Fruits were more negatively affected by lower water potential values than leafy shoots, since fruit average dry mass at harvest was $49 \%$ lower in the case of a severe water stress than under control conditions (Table 3). The water stress affected positively the four sugars concentrations, with a stronger effect for glucose and fructose (Fig. 4). of application and has a positive effect on sugar concentrations at harvest (Table 4). Severe stress decreases the fruit yield and mass. When applied on stage II it has almost no effect on sugar concentrations whereas it produced significant increases in all sugar concentrations except

397 for sorbitol when applied during stage III (Table 4). It is interesting to note that the stress in 398 stage II had a significant and immediate effect on the concentrations of glucose and fructose, but this effect disappeared quickly when the stress stopped (Fig. 5).

When considering water stress scenarios close to real conditions, yield and fruit average dry mass at harvest were significantly affected by severe water stress. In contrast, leafy shoot

402 total and average masses were not significantly influenced by water stress (Fig 6). Regarding 403 sugar concentrations in fruit (Table 5), a severe water stress produced higher concentrations of 404 the four sugars accounted (sucrose, glucose, fructose and sorbitol); whereas a moderate water 
Version définitive du manuscrit publiée dans / Final version of the manuscript published in :

Agricultural Water Management (2013), Vol. 128, p. 1-12, DOI: 10.1016/agwat.2013.06.008,

Journal homepage: http://www.elsevier.com/locate/agwat

405 stress significantly increased the concentrations of sucrose, glucose and fructose but not that of

406 sorbitol (Fig 6).

407

408 4. Discussion

409

A middle-late maturing peach cultivar ('Catherine') was successfully implemented and

410 parameterised into QualiTree, a virtual tree model (Lescourret et al. 2011) that simulates the

411 within-tree variations in fruit and leafy-shoot dry masses. The parameterization of this middle-

412 late maturing peach cultivar broadened the predictive capacities of the model, since certain

413 parameters within QualiTree are cultivar dependent (Mirás-Avalos et al. 2011, 2012). Several

414 parameters differed in this cultivar compared to those of extra-early, early and late maturing

415 peach cultivars ('Flordastar', 'Alexandra' and 'Suncrest', respectively). The initial relative

416 growth rates of fruits and leafy shoots were, in 'Catherine', intermediate between those reported

417 for 'Alexandra' and 'Suncrest'. The same was observed for the maximal dry weight of fruits

418 (for a complete set of parameters for 'Alexandra' and 'Suncrest' cultivars see Mirás-Avalos et

419 al. 2011). Moreover, the parameter expressing the effect of distance between tree objects on

420 carbon exchange within the tree ( $k$, see Lescourret et al. 2011) was very low, indicating that

421 within-tree distances were not limiting as was observed for 'Flordastar', 'Alexandra' and

422 'Suncrest' (Mirás-Avalos et al. 2011, 2012). This agrees with field data reported by Lopez et al.

423 (2007). Furthermore, a novel advance in the model issued from the current work is the

424 parameterisation for four sugars (glucose, fructose, sucrose and sorbitol) enhancing the

425 predictive capabilities of QualiTree since now it is able to offer information on fruit quality as

426 well as on fruit size.

427 QualiTree also reproduced satisfactorily the observed fruit and leafy shoot growth of a

428 peach tree cv. 'Catherine' subject to water stress, a major factor affecting fruit and vegetative

429 growth (Mercier et al. 2009; Lopez et al. 2010), even though the model evaluation did not

430 consider the possible heterogeneity of leaf response to water stress due to a high variability of

431 irradiation within the canopy (Díaz-Espejo et al., 2007). The model was also capable of

432 reproducing the observed concentrations of four sugars (sucrose, fructose, glucose and sorbitol), 
Version définitive du manuscrit publiée dans / Final version of the manuscript published in :

Agricultural Water Management (2013), Vol. 128, p. 1-12, DOI: 10.1016/agwat.2013.06.008,

Journal homepage: http://www.elsevier.com/locate/agwat

433 in the fruit flesh. However, sucrose was overestimated in both FI and RDI trees and fructose

434 was overestimated under RDI conditions, suggesting that further improvements are necessary.

435 Simulation scenarios allowed us to observe that, for a middle-late maturing peach

436 cultivar ('Catherine'), significant reductions in fruit size appeared at $\psi_{1}$ of $-2 \mathrm{MPa}$. However,

437 leafy shoots were less sensitive to water stress than fruits, as they were significantly affected only by $\psi_{1}$ lower than $-2.5 \mathrm{MPa}$.

In contrast, all the sugar concentrations increased continuously with the water stress

440 when it is applied from the beginning of the simulation. However, it does not predict a higher

441 sensitivity of sorbitol than sucrose, which is not in agreement with the results of Lo Bianco et al.

$442(2000)$.

443 Simulation results are in accordance with several field studies that reported an enhancement of fruit quality under RDI conditions. For instance, Crisosto et al. (1994) and

445 Intrigliolo and Castel (2010) observed that deficit irrigation increased total soluble solids 446 content in fruits. Besset et al (2001) observed a greater content in total soluble solids in fruits 447 from peach trees under water stress conditions when compared to fully irrigated trees. These 448 results also agreed with data reported by Intrigliolo and Castel (2010) for prunes, as they 449 observed an improvement in fruit composition in trees under regulated deficit irrigation conditions. In addition, Barry et al. (2004) observed, in citrus, that withholding water from trees during stage II of fruit development increased the concentrations of fructose and glucose.

452 Moreover, sorbitol, glucose and fructose have been reported to be partitioned according to the 453 relative size of the fruit (Lo Bianco and Rieger, 2002). Thus, taking into account that irrigation 454 affects fruit final size (Bryla et al., 2005; Lopez et al., 2011), sugar concentrations in fruit flesh may also be affected. In view of the results from our simulations, QualiTree may provide useful information on sugar contents in fruit flesh.

Our results validate the fact that RDI strategies allow the maintenance or even enhancement of fruit quality while saving water as suggested by several field studies (Besset et al., 2001; Fereres and Soriano, 2007; Intrigliolo and Castel, 2010; Lopez et al., 2011). 
Version définitive du manuscrit publiée dans / Final version of the manuscript published in :

Agricultural Water Management (2013), Vol. 128, p. 1-12, DOI: 10.1016/agwat.2013.06.008,

Journal homepage: http://www.elsevier.com/locate/agwat

The simulations allowed us to observe what would happen when trees were imposed to

462 different levels of water stress two weeks before fruit harvest. This period is critical for final

463 fruit size. According to QualiTree, no significant effects were observed on fruit yield when

464 water stress was moderate (-0.9 and $-1.5 \mathrm{MPa}$ for $\psi_{\mathrm{s}}$ and $\psi_{1}$, respectively) but significant

465 increases in sucrose, glucose, fructose and sorbitol in fruit flesh were detected. However, when

466 a severe water stress (-1.6 and $-3 \mathrm{MPa}$ for $\psi_{\mathrm{s}}$ and $\psi_{1}$, respectively) occurred, significant

467 reductions in fruit yield (22\% less than under control conditions) were predicted and they may

468 not be compensated by the increase in sugar contents in the fruit flesh. The results of our

469 simulations are in accordance with other simulation studies (Génard et al. 2009).

470

471

472 Acknowledgements. We are grateful to the IRRIQUAL (EU-FP6-FOOD-CT-2006-023120)

473 and SIRRIMED (KBBE-2009-1-2-03, PROPOSAL N² 245159) projects for financial support.

474 We also acknowledge two SENECA projects (05665/PI/07 and 11872/PI/09) and

475 CONSOLIDER INGENIO 2010 (MEC CSD2006-0067) and CICYT (AGL2010-17553)

476 projects for funding this research. J.M. Mirás-Avalos thanks Xunta de Galicia for funding his

477 contract within the framework of the program "Isidro Parga Pondal".

478

479

\section{SUPPORTING INFORMATION}

480 Additional Supporting Information may be found in the online version of this article:

481 Table S1. Inputs for QualiTree

482 Table S2. Ouputs from QualiTree

483 Table S3. Parameter values concerning carbon economy and fruit quality in QualiTree

484

485 References

486 Abrisqueta, I., Tapia, L.M., Conejero, W., Sánchez-Toribio, M.I., Abrisqueta, J.M., Vera, J., 487 Ruiz-Sanchez, M.C., 2010. Response of early-peach [Prunus persica (L.)] trees to deficit 488 irrigation. Span. J. Agric. Res. 8(S2), S30-S39. 
Version définitive du manuscrit publiée dans / Final version of the manuscript published in :

Agricultural Water Management (2013), Vol. 128, p. 1-12, DOI: 10.1016/agwat.2013.06.008,

Journal homepage: http://www.elsevier.com/locate/agwat

489 Aguirrezábal, L.A.N, Martre, P., Pereyra-Irujo, G., Izquierdo, N., Allard, V., 2009.

490 Management and breeding strategies for the improvement of grain and fruit quality. In:

491 Sadras, V.O., Miralles, D.J. (eds.). Crop physiology: Applications for genetic

492 improvement and agronomy. San Diego, CA, USA. Academic Press, 387-421.

493 Allen, R.G., Pereira, L.S., Raes, D., Smith, M., 1998. Crop evapotranspiration - guidelines for

495

496

497 computing crop water requirements. Irrigation and Drainage 56, FAO, Rome, 300 p.

Allen, M.T., Prusinkiewicz, P., DeJong, T.M., 2005. Using L-systems for modelling source-sink interactions, architecture and physiology of growing trees: the L-PEACH model. New Phytol. 166(3): 869-880.

498

Barry, G.H., Castle, W.S., Davies, F.S., 2004. Rootstocks and plant water relations affect sugar

500 accumulation of citrus fruit via osmotic adjustment. J. Amer. Soc. Hort. Sci. 129(6), 881889.

501

Ben Mimoun, M., Lescourret, F., Génard, M., 1999. Modeling carbon allocation in peach shoot bearing fruits: simulation of the water stress effect. Fruits 54, 129-134.

Berman, M.E., DeJong, T.M., 1996. Water stress and crop load effects on fruit fresh and dry weights in peach (Prunus persica). Tree Physiol. 16, 859-864.

Berman, M.E., DeJong, T.M., 2003. Seasonal patterns of vegetative growth and competition with reproductive sinks in peach (Prunus persica). J. Horticult. Sci. Biotechnol. 78(3), 303-309.

511 Bryla, D.R., Dickson, E., Shenk, R., Scott Johnson, R., Crisosto, C.H., Trout, T.J., 2005. Influence of irrigation method and scheduling on patterns of soil and tree water status and its relation to yield and fruit quality in peach. HortScience 40(7), 2118-2124.

514 Bussi, C., Lescourret, F., Mercier, V., Génard, M., 2010. Effects of winter pruning and of water restriction on fruit and vegetative growth, water potential and leaf gas exchange during 
Version définitive du manuscrit publiée dans / Final version of the manuscript published in :

Agricultural Water Management (2013), Vol. 128, p. 1-12, DOI: 10.1016/agwat.2013.06.008,

Journal homepage: http://www.elsevier.com/locate/agwat

543 Fereres, E., Goldhamer, D.A., 1990. Deciduous fruit and nut trees, in: Stewart, B.A., Nielsen, D.R. (Eds.), Irrigation of Agricultural Crops. A.S.A. Madison, WI, Monograph 30, pp. 987-1017.

Fereres, E., Soriano, M.A., 2007. Deficit irrigation for reducing agricultural water use. J. Exp. Bot. 58, 147-159.

Fishman, S., Génard, M., 1998. A biophysical model of fruit growth: simulation of seasonal and diurnal dynamics of mass. Plant Cell Environ. 21(8), 739-752.

550

Génard, M., Lescourret, F., Ben Mimoun, M., Besset, J., Bussi, C., 1998. A simulation model of growth at the shoot-bearing fruit level. II. Test and effect of source and sink factors in the case of peach. Eur. J. Agron. 9, 189-202.

Génard, M., Lescourret, F., Gomez, L., Habib, R., 2003. Changes in fruit sugar concentrations in response to assimilate supply, metabolism and dilution: a modeling approach applied to peach fruit (Prunus persica). Tree Physiol. 23, 373-385.

Génard, M., Gibert, C., Bruchou, C., Lescourret, F., 2009. An intelligent virtual fruit model focusing on quality attributes. J. Hortic. Sci. Biotecnol. SI, 157-163.

Girona, J., Gelly, M., Mata, M., Arbonès, A., Rufat, J., Marsal, J., 2005. Peach tree response to single and combined deficit irrigation regimes in deep soils. Agr. Water Manage. 72:97108.

Gomez, L. Rubio, E., Augé, M., 2002. A new procedure for extraction and measurement of soluble sugars in ligneous plants. J. Sci. Food Agric. 82, 360-369.

Grossman, Y.L., DeJong, T.M., 1994. Carbohydrate requirements for dark respiration by peach vegetative organs. Tree Physiol. 14, 37-48.

Harrison, R.D., Daniell, J.W., Cheshire, J.M., 1989. Net photosynthesis and stomatal conductance of peach seedlings and cutting in response to changes in soil water potential. J. Am. Soc. Hortic. Sci. 114, 986-990.

Hipps. N.A., Pagès, L., Huguet, J.G., Serra, V., 1995. Influence of controlled water suplí on shoot and root development of young peach trees. Tree Physiol. 15, 95-103. 
Version définitive du manuscrit publiée dans / Final version of the manuscript published in :

Agricultural Water Management (2013), Vol. 128, p. 1-12, DOI: 10.1016/agwat.2013.06.008,

Journal homepage: http://www.elsevier.com/locate/agwat

596 Lopez, G., Behboudian, M.H., Echeverria, G., Girona, J., Marsal, J., 2011. Instrumental and sensory evaluation of fruit quality for 'Ryan's Sun' peach grown under déficit irrigation. HortTechnology 21, 712-719.

Martre, P., Bertin, N., Salon, C., Génard, M., 2011. Modelling the size and composition of fruit, grain and seed by process-based simulation models. New Phytol. 191, 601-618.

601

602

603

604

Mercier, V., Bussi, C., Lescourret, F., Génard, M., 2009. Effects of different irrigation regimes

605 applied during the final stage of rapid growth on an early maturing peach cultivar. Irrig.

606 Sci. 27, 297-306.

607

Mirás-Avalos, J.M., Egea, G., Nicolás, E., Génard, M., Vercambre, G., Moitrier, N., Valsesia, 608 P., González-Real, M.M., Bussi, C., Lescourret, F., 2011. QualiTree, a virtual fruit tree to study the management of fruit quality. II. Parameterisation for peach, analysis of growthrelated processes and agronomic scenarios. Trees Struct. Funct. 25, 785-799.

Mirás-Avalos, J.M., Alcobendas, R., Alarcón, J.J., Pedrero, F., Valsesia, P., Lescourret, F., Nicolás, E., 2012. Combined effects of water stress and fruit thinning on fruit and

Reynolds, J.F., Chen, J.L., 1996. Modelling whole-plant allocation in relation to carbon and nitrogen supply: coordination versus optimization: opinion. Plant Soil 185(1), 65-74.

Rieger, M., Marra, F., 1994. Responses of young peach trees to root confinement. J. Am. Soc. Hortic. Sci. 119, 223-228. 


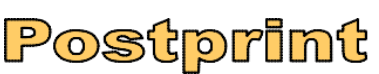

Version définitive du manuscrit publiée dans / Final version of the manuscript published in :

Agricultural Water Management (2013), Vol. 128, p. 1-12, DOI: 10.1016/agwat.2013.06.008,

Journal homepage: http://www.elsevier.com/locate/agwat

622 Solari, L.I., Johnson, S., DeJong, T.M., 2006. Relationship of water status to vegetative growth

623 and leaf gas exchange of peach (Prunus persica) trees on different rootstocks. Tree

$624 \quad$ Physiol. 26, 1333-1341.

625 
Version définitive du manuscrit publiée dans / Final version of the manuscript published in :

Agricultural Water Management (2013), Vol. 128, p. 1-12, DOI: 10.1016/agwat.2013.06.008, Journal homepage: http://www.elsevier.com/locate/agwat

\section{Tables}

628 Table 1. Parameter values concerning carbon economy and sugar development in QualiTree for

cv. 'Catherine'.

\begin{tabular}{|c|c|c|c|c|}
\hline Parameter & Definition (corresponding equation) & Unit & Value & Origin \\
\hline \multicolumn{5}{|c|}{ Global parameters } \\
\hline SReq & Shoot:root ratio at equilibrium (Eq. 4) & Dimensionless & 4.6 & $\begin{array}{l}\text { Grossman and DeJong (1994); } \\
\text { Rieger and Marra (1994), Hipps et } \\
\text { al. (1995), Mediene et al. (2002) }\end{array}$ \\
\hline$K$ & $\begin{array}{l}\text { Parameter expressing the effect of distance between organs } \\
\text { on carbon exchange within the tree (Eq. } 5 \text { ) }\end{array}$ & Dimensionless & 0.002 & This work \\
\hline \multicolumn{5}{|c|}{ Specific parameters for leafy shoots } \\
\hline$d d_{\min }$ & Minimum degree-day value (Eq. 3) & degree-days & 600 & This work \\
\hline$d d_{\max }$ & Maximum degree-day value (Eq. 3) & degree-days & 2800 & This work \\
\hline$R G R_{l s}^{i n i}$ & Leafy shoot initial relative growth rate (Eq. 2) & degree-days ${ }^{-1}$ & $2 \times 10^{-3}$ & This work \\
\hline$D M_{l s}^{\max }$ & Leafy shoot maximal dry mass (Eq. 2) & g & 66 & This work \\
\hline \multicolumn{5}{|c|}{ Specific parameters for fruits } \\
\hline$d d_{\min }$ & Minimum degree-day value (Eq. 3) & degree-days & 600 & This work \\
\hline$d d_{\max }$ & Maximum degree-day value (Eq. 3) & degree-days & 3500 & This work \\
\hline$R G R_{f}^{i n i}$ & Fruit initial relative growth rate (Eq. 2) & degree-days ${ }^{-1}$ & $37 \times 10^{-4}$ & This work \\
\hline$D M_{f}^{\max }$ & Potential dry mass of fruits at maturity (Eq. 2) & g & 55 & This work \\
\hline \multicolumn{5}{|c|}{ Growth for different structural parts } \\
\hline$R G R_{o w}{ }^{i n i}$ & Old wood and coarse root initial relative growth rate (Eq. 1) & degree-days $^{-1}$ & $4 \times 10^{-4}$ & Mirás-Avalos et al. (2011) \\
\hline$R G R_{f r}^{i n i}$ & Fine root initial relative growth rate (Eq. 2) & degree-days ${ }^{-1}$ & 0.04 & This work \\
\hline$R G R_{s w}{ }^{i n i}$ & Stem wood initial relative growth rate (Eq. 1) & degree-days $^{-1}$ & $7 \times 10^{-4}$ & Berman and DeJong (2003) \\
\hline \multicolumn{5}{|c|}{ Partitioning of carbon flow from the phloem into sugars } \\
\hline$\lambda_{p h}$ & Proportion of carbon as sucrose in the phloem sap (Eq. 6) & Dimensionless & 0.48 & This work \\
\hline$k_{1,1}$ & Relative rate of decrease of $k_{1(t)}($ Eq. 6) & day $^{-1}$ & 0.12 & Génard et al. (2003) \\
\hline$k_{1,2}$ & Time at which $k_{l(t)}=1$ day $^{-1}$ (Eq. 6) & day & 65 & This work \\
\hline$k_{2}$ & Relative rate of sorbitol transformation to glucose (Eq. 6) & day $^{-1}$ & 0.42 & This work \\
\hline$k_{3}$ & Relative rate of sorbitol transformation to fructose (Eq. 6) & day $^{-1}$ & 0.6 & This work \\
\hline$k_{4}$ & $\begin{array}{l}\text { Ratio of the relative rate of glucose and fructose } \\
\text { transformation to the relative growth rate (Eq. } 6 \text { ) }\end{array}$ & Dimensionless & 2.5 & This work \\
\hline \multicolumn{5}{|c|}{ Water stress on photosynthesis } \\
\hline$A_{h}$ & (Eq. 7) & $\mathrm{MPa}^{-1}$ & 0.22 & Harrison et al., 1989 \\
\hline$B_{h}$ & (Eq. 7) & $\mathrm{MPa}$ & 4.43 & Harrison et al., 1989 \\
\hline \multicolumn{5}{|c|}{ Duration of the different phenological stages } \\
\hline$I$ & Beginning of Stage I of fruit development & DAFB & 18 & Field data \\
\hline II & Beginning of Stage II of fruit development & DAFB & 49 & Field data \\
\hline III & Beginning of Stage III of fruit development & DAFB & 76 & Field data \\
\hline$H$ & Harvest & DAFB & 105 & Field data \\
\hline
\end{tabular}

630 
Version définitive du manuscrit publiée dans / Final version of the manuscript published in :

Agricultural Water Management (2013), Vol. 128, p. 1-12, DOI: 10.1016/agwat.2013.06.008, Journal homepage: http://www.elsevier.com/locate/agwat

637 Table 3. Mean values at harvest $(\mathrm{DAFB}=105)$ for yield, fruit and shoot dry mass and

638 concentrations of sucrose, glucose, fructose and sorbitol according to the theoretical water stress

639 scenarios. Significant differences are indicated. Values correspond to dry mass and grams of the 640 corresponding sugar per gram of fruit fresh mass.

641

642

\begin{tabular}{|l|l|l|l|l|l|l|l|l|}
\hline \multicolumn{1}{|c|}{ Scenario } & \multicolumn{4}{|c|}{ Dry mass (g) } & \multicolumn{3}{c|}{ Concentration $\left(\mathrm{g}\right.$ g fresh mass $\left.{ }^{-1}\right)$} \\
\hline & $\begin{array}{l}\text { Yield } \\
(\mathrm{g} / \mathrm{FU})\end{array}$ & $\begin{array}{l}\text { Fruit } \\
\text { average } \\
\text { mass }\end{array}$ & $\begin{array}{l}\text { Leafy } \\
\text { shoot } \\
\text { total } \\
\text { mass } \\
(\mathrm{g} / \mathrm{FU})\end{array}$ & $\begin{array}{l}\text { Leafy } \\
\text { shoot } \\
\text { average } \\
\text { mass }\end{array}$ & Sucrose & Glucose & Fructose & Sorbitol \\
\hline Control & $23.65^{\mathrm{b}}$ & $19.70^{\mathrm{d}}$ & $155.20^{\mathrm{a}}$ & $15.01^{\mathrm{b}}$ & $0.049^{\mathrm{a}}$ & $0.010^{\mathrm{a}}$ & $0.013^{\mathrm{a}}$ & $0.0030^{\mathrm{a}}$ \\
\hline Stress 1 & $22.41^{\mathrm{b}}$ & $18.68^{\mathrm{cd}}$ & $149.48^{\mathrm{a}}$ & $14.46^{\mathrm{b}}$ & $0.060^{\mathrm{b}}$ & $0.012^{\mathrm{b}}$ & $0.016^{\mathrm{b}}$ & $0.0035^{\mathrm{b}}$ \\
\hline Stress 2 & $19.99^{\mathrm{ab}}$ & $16.67^{\mathrm{c}}$ & $141.23^{\mathrm{a}}$ & $13.67^{\mathrm{ab}}$ & $0.062^{\mathrm{c}}$ & $0.013^{\mathrm{c}}$ & $0.017^{\mathrm{c}}$ & $0.0036^{\mathrm{b}}$ \\
\hline Stress 3 & $16.25^{\mathrm{ab}}$ & $13.54^{\mathrm{b}}$ & $130.80^{\mathrm{a}}$ & $12.66^{\mathrm{ab}}$ & $0.066^{\mathrm{d}}$ & $0.014^{\mathrm{d}}$ & $0.020^{\mathrm{d}}$ & $0.0039^{\mathrm{c}}$ \\
\hline Stress 4 & $12.44^{\mathrm{a}}$ & $10.35^{\mathrm{a}}$ & $119.36^{\mathrm{a}}$ & $11.56^{\mathrm{a}}$ & $0.063^{\mathrm{c}}$ & $0.016^{\mathrm{e}}$ & $0.021^{\mathrm{e}}$ & $0.0038^{\mathrm{c}}$ \\
\hline
\end{tabular}

643

644 
Version définitive du manuscrit publiée dans / Final version of the manuscript published in :

Agricultural Water Management (2013), Vol. 128, p. 1-12, DOI: 10.1016/agwat.2013.06.008, Journal homepage: http://www.elsevier.com/locate/agwat

644 Table 4. Mean values at harvest $(\mathrm{DAFB}=105)$ for yield, fruit and shoot dry mass and

645 concentrations of sucrose, glucose, fructose and sorbitol according to the theoretical water stress

646 scenarios with two times of occurrence. Significant differences are indicated. Values correspond

647 to dry mass and grams of the corresponding sugar per gram of fruit fresh mass.

648

649

\begin{tabular}{|l|l|l|l|l|l|l|l|l|}
\hline \multicolumn{1}{|c|}{ Scenario } & \multicolumn{4}{|c|}{ Dry mass (g) } & \multicolumn{3}{c|}{ Concentration $(\mathrm{g}$ g fresh mass } \\
\hline & $\begin{array}{l}\text { Yield } \\
\text { (g/FU) }\end{array}$ & $\begin{array}{l}\text { Fruit } \\
\text { average } \\
\text { mass }\end{array}$ & $\begin{array}{l}\text { Leafy } \\
\text { shoot } \\
\text { total } \\
\text { mass } \\
\text { (g/FU) }\end{array}$ & $\begin{array}{l}\text { Leafy } \\
\text { shoot } \\
\text { average } \\
\text { mass }\end{array}$ & Sucrose & Glucose & Fructose & Sorbitol \\
\hline Control & $23.65^{\mathrm{b}}$ & $19.70^{\mathrm{b}}$ & $155.20^{\mathrm{a}}$ & $15.01^{\mathrm{a}}$ & $0.049^{\mathrm{a}}$ & $0.010^{\mathrm{a}}$ & $0.013^{\mathrm{a}}$ & $0.0030^{\mathrm{a}}$ \\
\hline Stress in stage II & $23.42^{\mathrm{b}}$ & $19.52^{\mathrm{b}}$ & $153.39^{\mathrm{a}}$ & $14.84^{\mathrm{a}}$ & $0.061^{\mathrm{b}}$ & $0.012^{\mathrm{b}}$ & $0.016^{\mathrm{b}}$ & $0.0037^{\mathrm{b}}$ \\
\hline Stress in stage III & $23.21^{\mathrm{b}}$ & $19.35^{\mathrm{b}}$ & $153.97^{\mathrm{a}}$ & $14.89^{\mathrm{a}}$ & $0.059^{\mathrm{b}}$ & $0.012^{\mathrm{b}}$ & $0.016^{\mathrm{b}}$ & $0.0034^{\mathrm{b}}$ \\
\hline Severe stress in stage II & $19.84^{\mathrm{ab}}$ & $16.52^{\mathrm{a}}$ & $142.79^{\mathrm{a}}$ & $13.82^{\mathrm{a}}$ & $0.050^{\mathrm{a}}$ & $0.010^{\mathrm{a}}$ & $0.013^{\mathrm{a}}$ & $0.0035^{\mathrm{b}}$ \\
\hline Severe stress in stage III & $18.44^{\mathrm{a}}$ & $15.36^{\mathrm{a}}$ & $146.77^{\mathrm{a}}$ & $14.20^{\mathrm{a}}$ & $0.061^{\mathrm{b}}$ & $0.017^{\mathrm{c}}$ & $0.023^{\mathrm{c}}$ & $0.0029^{\mathrm{a}}$ \\
\hline
\end{tabular}

651

652

653

654 
Version définitive du manuscrit publiée dans / Final version of the manuscript published in :

Agricultural Water Management (2013), Vol. 128, p. 1-12, DOI: 10.1016/agwat.2013.06.008, Journal homepage: http://www.elsevier.com/locate/agwat

654 Table 5. Mean values at harvest $(\mathrm{DAFB}=105)$ for yield, fruit and shoot dry mass and

655 concentrations of sucrose, glucose, fructose and sorbitol according to the agronomic water stress

656 scenarios. Significant differences are indicated. Values correspond to dry mass and grams of the

657 corresponding sugar per gram of fruit fresh mass.

658

659

\begin{tabular}{|l|l|l|l|l|l|l|l|l|}
\hline \multicolumn{1}{|c|}{ Scenario } & \multicolumn{4}{|c|}{ Dry mass (g) } & \multicolumn{3}{c|}{ Concentration $\left(\mathrm{g}\right.$ g fresh mass $\left.{ }^{-1}\right)$} \\
\hline & $\begin{array}{l}\text { Yield } \\
(\mathrm{g} / \mathrm{FU})\end{array}$ & $\begin{array}{l}\text { Fruit } \\
\text { average } \\
\text { mass }\end{array}$ & $\begin{array}{l}\text { Leafy } \\
\text { shoot } \\
\text { total } \\
\text { mass } \\
(\mathrm{g} / \mathrm{FU})\end{array}$ & $\begin{array}{l}\text { Leafy } \\
\text { shoot } \\
\text { average } \\
\text { mass }\end{array}$ & Sucrose & Glucose Fructose & Sorbitol \\
\hline Control & $22.69^{\mathrm{b}}$ & $18.92^{\mathrm{c}}$ & $152.42^{\mathrm{a}}$ & $14.74^{\mathrm{a}}$ & $0.058^{\mathrm{a}}$ & $0.012^{\mathrm{a}}$ & $0.016^{\mathrm{a}}$ & $0.0032^{\mathrm{a}}$ \\
\hline Moderate stress & $19.65^{\mathrm{ab}}$ & $16.39^{\mathrm{b}}$ & $145.73^{\mathrm{a}}$ & $14.10^{\mathrm{a}}$ & $0.066^{\mathrm{b}}$ & $0.016^{\mathrm{b}}$ & $0.021^{\mathrm{b}}$ & $0.0034^{\mathrm{a}}$ \\
\hline Severe stress & $16.53^{\mathrm{a}}$ & $13.77^{\mathrm{a}}$ & $137.36^{\mathrm{a}}$ & $13.29^{\mathrm{a}}$ & $0.082^{\mathrm{c}}$ & $0.023^{\mathrm{c}}$ & $0.030^{\mathrm{c}}$ & $0.0044^{\mathrm{b}}$ \\
\hline
\end{tabular}

660

661

662 
Version définitive du manuscrit publiée dans / Final version of the manuscript published in :

Agricultural Water Management (2013), Vol. 128, p. 1-12, DOI: 10.1016/agwat.2013.06.008,

Journal homepage: http://www.elsevier.com/locate/agwat

662 Figures

663

664 Figure 1. Experimental design layout of the field experiment. The coloured trees were 665 implemented in QualiTree.

666

667 Figure 2. Test of the model against experimental data for the three Catherine trees analysed (FI 668 tree 1, FI tree 2, and RDI tree) under different conditions. Variation of leafy shoot growth and 669 fruit growth among monitored shoots (mean $\pm \mathrm{SD}$ ) according to DAFB, either observed (black 670 squares and black lines) or simulated (white circles and dotted lines). The total number of FU 671 (n) is indicated on each plot. Results from FI tree 1 corresponded to the calibration of the model, 672 whereas those from FI tree 2 and RDI tree refer to the validation of the model.

673

674 Figure 3. Test of the model against experimental data for the three Catherine trees analysed (FI 675 tree 1, FI tree 2 and RDI tree). Variation of sugar concentrations among monitored fruits (mean $676 \pm \mathrm{SD}$ ) according to DAFB, either observed (black squares and black lines) or simulated (white 677 circles and dotted lines). The total number of FU (n) is indicated on each plot. Results from FI tree 1 corresponded to the calibration of the model, whereas those from FI tree 2 and RDI tree refer to the validation of the model.

680

681 Figure 4. Simulation of the effect of different leaf and stem water potentials (expressed in MPa) 682 on leafy shoot (LS) and fruit growth in dry mass, and on the concentrations in the fruit flesh of 683 four reducing sugars according to days after bloom. See the description of theoretical water 684 stress scenarios for further details.

685

686 Figure 5. Simulation of the effect of two levels and application times of water stress on sugar 687 concentrations in the fruit according to days after bloom. The change in the leaf and stem water 688 potentials (expressed in MPa) occurs at 76 days after bloom (stage II of fruit development) or at 
Version définitive du manuscrit publiée dans / Final version of the manuscript published in :

Agricultural Water Management (2013), Vol. 128, p. 1-12, DOI: 10.1016/agwat.2013.06.008,

Journal homepage: http://www.elsevier.com/locate/agwat

68990 days after bloom (stage III of fruit development). See the description of theoretical water

690 stress scenarios for further details.

691

692 Figure 6. Simulation of the effect of different agronomic scenarios (see the text for further

693 details) on the leafy shoot (LS) total and average dry masses, fruit yield, fruit average dry mass,

694 and on the concentrations in the fruit flesh of four sugars according to days after bloom.

695 